\title{
Effects of land abandonment and changing habitat structure on avian assemblages in upland pastures of Bulgaria
}

\author{
STOYAN C. NIKOLOV
}

\begin{abstract}
Summary
Over the past half century, grassland birds in Europe have declined dramatically and in order to maintain and restore their populations it is critical to understand how habitat structures and quality within pastures affect birds. This study investigated the effects of habitat structure and pasture abandonment on grassland birds in IBA Ponor, western Bulgaria. Birds were sampled using the point count method at 143 randomly located circular plots and a total of 1,401 observations of birds from 31 species were recorded. The results showed that habitat complexity, management and landscape position influenced bird community structure and species occurrence within the upland pastures. Extensively grazed pastures supported higher structural complexity of vegetation cover and higher bird-species richness and diversity compared with abandoned ones. Moreover, bird species with a preference for grazed rather than abandoned pastures had higher conservation status and most were associated with shrub cover. To maintain high levels of avian diversity, habitat complexity within pastures should be maintained through extensive grazing, to ensure availability of scrub vegetation wherever possible. Finally, this study provided evidence that agri-environmental schemes should not be directly extrapolated from one country or region to another without been tested first, because within the same management, differences in habitat structural characteristics may exist due to the landscape and socio-economic characteristics of the region.
\end{abstract}

\section{Introduction}

More than half of the world's temperate grasslands are devoted to agriculture (Hannah et al. 1995), which leaves farmlands as the primary breeding habitat for many species. Many of these species are extremely vulnerable to land management, and a dramatic decline in grassland bird populations resulting from the intensification of agricultural practices over the past half century was reported in Europe (Donald et al. 2001, 2006). In this respect, pastures seem to be an important semi-natural habitat for both socio-economic and ecological reasons, and changes in intensity or timing of their use influence ecosystem functioning (Fuller and Gough 1999, Klimešová et al. 2008). As well as intensification, land abandonment is a problem that has been widespread in Europe over the last 20 years, but has received less attention (Suárez-Seoane et al. 2002, Sirami et al. 2008). The existing knowledge on this subject comes from Western and Central Europe (e.g., Atkinson et al. 2004, Pavel 2004, Báldi et al. 2005, Batáry et al. 2007a,b) while Eastern European countries (EEC) are still poorly studied.

Most temperate grasslands require periodic clearing to control succession and grazing animals have a unique role to play by maintaining and enhancing structural heterogeneity of the sward (Rook and Tallowin 2003). As a primary consequence of pasture abandonment, changes in vegetation structure appear, with subsequent effects on bird populations through the loss of preferred breeding sites, alteration of food supplies and predation pressure (Fuller and Gough 1999). Grassland abandonment is generally followed by an increase in woody vegetation cover and 
there is evidence (Preiss et al. 1997, MacDonald et al. 2000, Suárez-Seoane et al. 2002, Verhulst et al. 2004, Vallecillo et al. 2008) that birds associated with scrub and woodland vegetation benefit from land abandonment, while those tied to open habitats are negatively affected (but see Sirami et al. 2008). In Central Europe, extensively grazed pastures hold more diverse, speciesrich and abundant avian communities than intensively used pastures, but the highest values of these community parameters were found in abandoned pastures (Verhulst et al. 2004). However, land abandonment should not be assumed to benefit wildlife conservation in Europe, because many high priority bird species are associated with the semi-natural habitats produced by low intensity farming (Suárez-Seoane et al. 2002, Kati and Sekercioglu 2006), and land abandonment is thought to be a major cause of their declines (Ostermann 1998, Sirami et al. 2008).

The ongoing changes in the agricultural economy of the EEC through implementation of agrienvironmental schemes provide a good opportunity to direct changes for the benefit of wildlife, but they have the potential to threaten species-rich ecosystems (Báldi et al. 2005) because they have been implemented without being tested within each country. Bulgaria recently joined the EU, and it faced the problem of how to keep its high wildlife diversity in the context of land use changes over the last 20 years (i.e. agricultural intensification in some areas and land abandonment in others). Evidence for negative trends in national populations of farmland birds already exists (Spasov 2008). To better understand the causes of these declines and to be able to reverse the declining population trends, scientifically sound research on how habitat structures and quality correlate with bird occurrence (Suárez-Seoane et al. 2002, Atkinson et al. 2004) and how birds select between differently managed habitats (Perlut et al. 2008) are required. Although data on these issues exist, they could not be directly extrapolated to Bulgaria because of landscape, economic and cultural differences and because these effects vary at local and landscape scale, and according to the habitat types under study (Suárez-Seoane et al. 2002, Atkinson et al. 2004, Tews et al. 2004).

The present study investigated bird-habitat relationships in upland pastures of the Important Bird Area (IBA) Ponor, a typical pastoral region for western Bulgaria. The objectives were: (I) to determine the main habitat features influencing bird community structure within upland pastures; (2) to compare bird community structure and species' habitat use among grazed and abandoned pastures; and (3) to propose management practices that could increase habitat quality and 'attractiveness' for declining farmland bird species.

\section{Methods}

Study area

Ponor is located about $50 \mathrm{~km} \mathrm{NW}$ of Sofia, western Bulgaria $\left(43^{\circ} \mathrm{O} 3^{\prime} \mathrm{N}-23^{\circ} 1 \mathrm{O}^{\prime} \mathrm{E}\right)$. The area covers 31,380 ha $(389-1,598 \mathrm{~m}$ elevation), and is recognized as a Special Protected Area (SPA) and an IBA (Nikolov et al. 2007). Ponor represents a characteristic karst area for Bulgaria, with a moderate continental climate: warm summers (mean $23^{\circ} \mathrm{C}$ ), cold winters (mean $-2^{\circ} \mathrm{C}$ ), and maximum rainfall in spring and early summer ( $900 \mathrm{~mm}$ in May and June) (Nikolov and Vassilev 2004). About $60 \%$ of the territory is covered by grasslands with xerophytic and mesophytic vegetation. The major land management is related to grazing and mowing with a small area of field crops. Before the communist regime was established in 1944, there was intensive stockbreeding in the area with more than 40,000 sheep. The creation of collective farms led to about a $50 \%$ decrease in livestock numbers, and after land privatization and collapse of state support in the 1990s, grazing animal numbers dropped sharply to no more than 3,000 sheep at present. As a result, large areas of pastures have been abandoned.

\section{Study design}

Prior to the field work, interviews with local stakeholders and municipalities were carried out to provide information on which grasslands were grazed before 1990 and which were still in use. 
A total of 143 point count stations (spaced at least $300 \mathrm{~m}$ apart) were randomly located within the grasslands for which information on grazing was available (Figure 1 ). Point count stations were verified and for those finally used, 54 fell within extensively grazed pastures and 89 were located within abandoned pastures.

For bird monitoring, each point count station was visited twice (in May and June 2008), in the morning (o6hoo-11 hoo) and in appropriate weather conditions. Birds were counted by a single observer (the author) using a point count technique (Gibbons and Gregory 2006) with a settling down period of $1 \mathrm{~min}$ and a counting period of $5 \mathrm{~min}$. Individuals seen or heard were recorded in four distance bands: (1) o-25 m, (2) 25-50 m, (3) 50-100 m, and (4) 100-200 m, with the aid of the laser rangefinder in Leica Geovid $10 \times 42$ binoculars. Fledglings and over-flying individuals (except territorial Eurasian Skylarks Alauda arvensis singing in flight) were not included, neither were raptors, swifts and swallows, because these birds use vast areas in searching for food and they are not appropriate indicators for the intensity of pasture use at the scale of the present study. Bird community structure was investigated on the basis of three derived variables: species richness (S), diversity and total abundance. The maximum numbers of species and individuals recorded on each point count station from both visits were considered for the analyses. Species diversity was calculated using the Shannon-Wiener diversity index $\left(H^{\prime}\right)$. Because grassland specialists and scrubland/woodland birds were expected to be affected differently by pasture abandonment, an additional analysis was carried out on these groups of birds. Species were classified within these two categories following Iankov (2007) (Appendix 1).

The following environmental data were collected within a radius of $50 \mathrm{~m}$ of each point's centre: elevation (measured by a GPSMAP 6oCS), cover of rocks and stones, and cover of the vegetation profiles: short sward $(<0.3 \mathrm{~m}$, consisting mainly of Chamaesartium sagittale, Lotus corniculatus, Carex caryophyllea, Trifolium alpestre, Luzula campestris and Festuca rubra); tall sward ( $>0.3 \mathrm{~m}$, consisting mainly of Agrostis capillaris, Anthoxanthum odoratum, Brachypodium pinnatum, Briza media, Verbascum spp. and Veratrum spp.); short shrubs $(<1.5 \mathrm{~m}$, consisting of Juniperus spp. and Rubus spp.); tall shrubs ( $1.5-3 \mathrm{~m}$, consisting of Rosa spp. and Crataegus monogyna); and trees ( $>3 \mathrm{~m}$, consisting mainly of Prunus cerasifera and Pinus sylvestris). Data

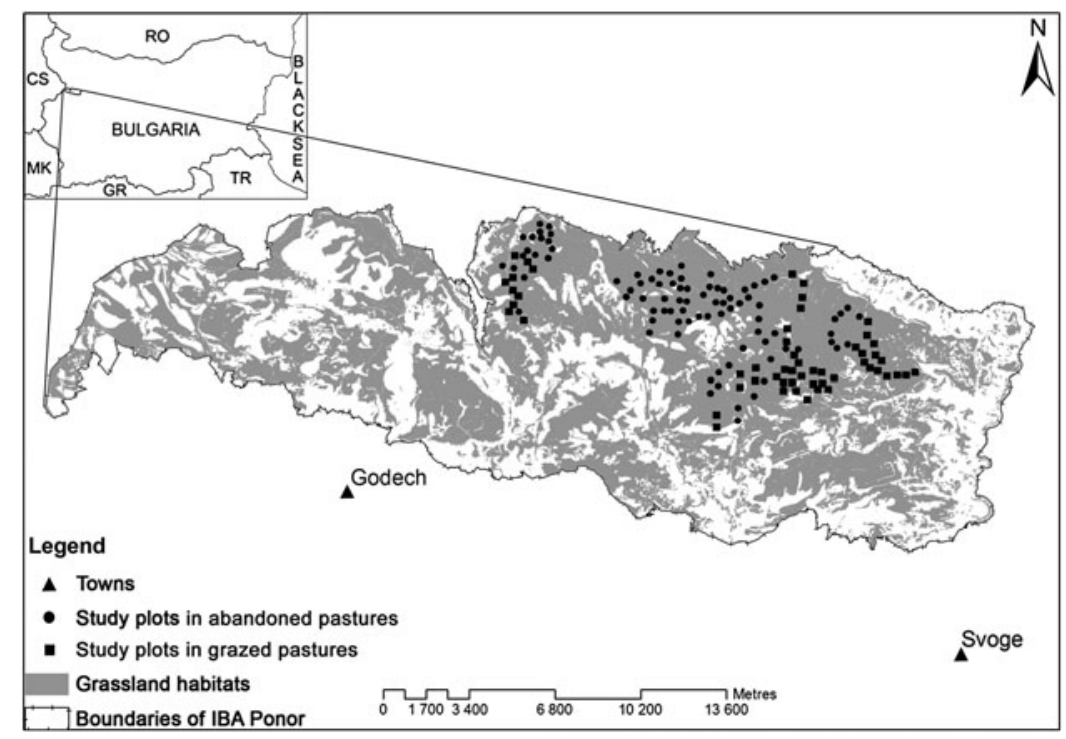

Figure 1. Location of IBA Ponor in Bulgaria and spatial distribution of the study plots (with radius $200 \mathrm{~m}$ ) within the studied area. 
on pasture use (grazed or abandoned) and location within the landscape (valley, slope or crest) were also collected. To measure habitat complexity, two additional variables were derived: habitat heterogeneity (computed using $H^{\prime}$ as a function of the proportions of habitat structures within the study plots) and richness of habitat structures.

\section{Data analyses}

Data were checked for normality using Shapiro-Wilk's test and those with non-normal distribution were transformed to obtain close-to-normal distributions: percent/proportions were arcsinetransformed and count data were square-root transformed (Krebs 1999). Comparisons between unpaired samples were made using t-test or Mann-Whitney $U$ test. Forward stepwise multiple regressions were used to determine the effects of habitat structure on bird community parameters. Environmental variables were checked for colinearity and a strong correlation was found between habitat heterogeneity and the number of habitat structures $(r=0.69, P<0.001)$. To avoid multicolinearity effects (Graham 2003), these two predictors were included in two separate multiple regression models. General Linear Modelling (GLM) was applied to analyze the effect of grazing, pasture position, and the interaction of these two factors on bird community parameters. The posthoc Tukey HSD test was used to determine significant differences between groups $(\alpha=0.05)$. Means were reported \pm 1 standard errors (SE). Levene's test was used to test for homogeneity of variances. All the aforementioned analyses were carried out in STATISTICA 7.0 (StatSoft 2004).

Relationships between environmental variables and abundances of bird species were determined by canonical correspondence analyses (CCA), applied using CANOCO 4.5. (ter Braak and Smilauer 2002). Length of gradient and suitability of using unimodal analyses were checked by detrended correspondence analysis (DCA). A Monte-Carlo test was used to assess the statistical significance of canonical axes.

Habitat preferences of birds were determined by calculation of the selection index according to the formula (Manly et al. 1993):

$$
w_{i}=\frac{o_{i}}{p_{i}}
$$

where $w_{i}$ is the selection index, $o_{i}$ and $p_{i}$ are respectively the observed and expected proportions of birds in habitat type $i$ ( $p_{i}$ was corrected for the uneven area covered by grazed and abandoned pastures). To test if birds were selecting studied habitats at random, the G-test was applied following the formula (Krebs 1999):

$$
G=2 \sum_{i=1}^{n}\left[u_{i} \ln \left(\frac{u_{i}}{U p_{i}}\right)\right]
$$

where $G$ is the likelihood ratio statistic $\left(\mathrm{H}_{\mathrm{o}}\right.$ : random selection), $n$ is the number of habitat types, $u_{i}$ is the number of observed birds in habitat type $i, U$ is the total number of birds observed. Only species with more than five observations and recorded in both habitat types were tested for their habitat preferences (Báldi et al. 2005).

Bird densities were calculated using DISTANCE 5.0 Release 2 (Thomas et al. 2006). A conventional Distance Sampling Analysis was applied because the study was conducted in habitats where the detection probability is similar (Buckland et al. 2001). The best Distance model was selected on the basis of the minimum value of Akaike's Information Criterion (AIC). Bird densities are reported with their detection probabilities (DP), coefficients of variation (CV) and $95 \%$ confidence intervals $(\mathrm{CI})$. Frequencies $(F)$ of birds were expressed in percentages as a proportion of point count stations where the species was observed from the total number of the point count stations visited (data were analyzed separately for grazed and abandoned pastures). 


\section{Results}

\section{Effects of habitat structure}

A total of 1,401 observations of birds belonging to 31 species were recorded (Appendix 1 ). The richness of habitat structures within the study plots was a good predictor for bird community structure in respect of species richness $\left(\beta=0.38, R^{2}=0.68, F_{5,137}=23.22, P<0.001\right)$ and diversity $\left(\beta=0.34, R^{2}=0.66, F_{4,138}=27.04, P<0.001\right)$, but a poor predictor for total bird abundance (all significant correlations were weak). In the multiple regression models containing habitat heterogeneity as a predictor (instead of the richness of habitat structures), the main habitat features determining bird community structure were the cover of short sward, habitat heterogeneity and cover of tall shrubs, influencing total abundance of birds, species richness and diversity, respectively (Table 1 ).

The ordination analysis showed that the two main environmental gradients determining bird species occurrences within upland pastures of IBA Ponor were vegetation height (decreasing with altitude and representing grassland succession) and habitat moisture (increasing from stony pastures to tall sward pastures) represented by the first and second canonical axes, respectively (Figure 2). Among grassland specialists, Eurasian Skylark, Tree Pipit Anthus trivialis and Whinchat Saxicola rubetra were associated with higher elevation and shorter sward, Corncrake Crex crex preferred taller sward, Northern Wheatear Oenanthe oenanthe and Eurasian Linnet Carduelis cannabina were more abundant in stony pastures, and Wood Lark Lullula arborea was associated with shrub cover. In respect of scrubland/woodland species, Red-backed Shrike Lanius collurio, Barred Warbler Sylvia nisoria and Corn Bunting Miliaria calandra were associated with trees and tall shrubs, while Greenfinch Carduelis chloris and Yellowhammer Emberiza citrinella preferred short shrubs.

\section{Pasture abandonment and birds}

Comparison between grazed and abandoned pastures showed that six out of nine studied environmental variables differed significantly between these two habitat types (Table 2). Grazed pastures had higher habitat heterogeneity and richness of habitat structures, were located at lower elevation and had more stony ground and scrubland cover than abandoned pastures. These differences in habitat structure between grazed and abandoned pastures affected their bird assemblages. Pasture use and landscape position were important predictors for bird community structure in upland pastures, while their interaction was not (Table 3). More species were found in grazed than in abandoned pastures ( 28 and 19 out of 31 species respectively) and grazed pastures supported significantly more species per point count station than abandoned pastures (grazed pastures: mean $S=3.53 \pm 0.19, n=54$ point count stations; abandoned pastures: mean $S=$ $2.80 \pm 0.17, n=89$ point count stations; Tukey HSD: $\left.M S_{137}=2.03, P=0.011\right)$. Total species diversity was also higher in grazed than abandoned pastures $\left(H^{\prime}=2.28\right.$ and 1.76 , respectively for used and abandoned pastures) and there was a statistically significant difference in the mean values of this community parameter per point count station (grazed pastures: mean $H^{\prime}=0.46 \pm$ $0.03, n=54$ point count stations; abandoned pastures: mean $H^{\prime}=0.37 \pm 0.02, n=89$ point count stations; Tukey HSD: $M S_{137}=0.04, P=0.021$ ). The only community parameter that did

Table 1 . Results from multiple regression analyses of the effects of habitat structure (richness of habitat structures was not included) on bird community parameters in the upland pastures of IBA Ponor, western Bulgaria.

\begin{tabular}{llrlrll}
\hline Bird community parameter & Factor & $\beta^{*}$ & $R^{2}$ & $F$ & \multicolumn{1}{c}{$\mathrm{df}$} & $P$ \\
\hline Total abundance & Cover of short sward & -0.36 & 0.26 & 9.79 & 5,137 & $<0.001$ \\
Species richness & Habitat heterogeneity & 0.45 & 0.64 & 32.35 & 3,139 & $<0.001$ \\
Species diversity & Tall scrub & 0.32 & 0.64 & 15.59 & 6,136 & $<0.001$ \\
\hline
\end{tabular}

${ }^{*}$ Non-significant $(P<0.05)$ or weak correlations $(|\beta|<0.3)$ are not shown. 


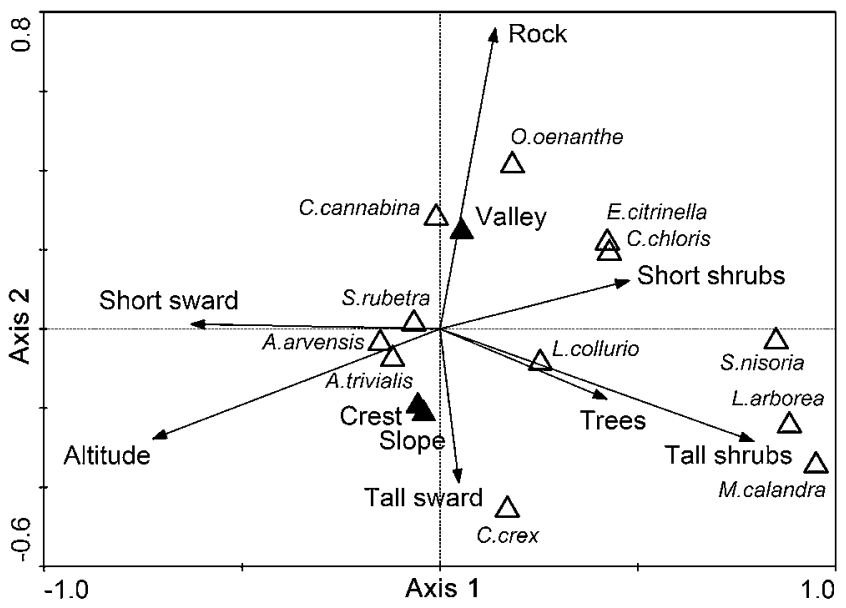

Figure 2. Two-dimensional ordination by CCA relating bird species abundances to habitat features within upland pastures of IBA Ponor, western Bulgaria. Together, first two axes explain $35.5 \%$ of bird data variability $(25.0 \%$ and $10.5 \%$ accounting for the first and second axis, respectively), and all axes are statistically significant (Monte-Carlo test based on 499 permutations, $F=3.87, P=0.002$ ). Nominal predictors are indicated as black triangles; continuous predictors are indicated as arrows; bird species are shown as empty triangles.

not differ significantly between grazed and abandoned pastures was total bird abundance (Tukey HSD: $\left.M S_{137}=4.25, P=0.106\right)$. Consequently, total bird density was very similar between these pasture categories: 4.17 birds $\mathrm{ha}^{-1}$ in grazed pastures (Hazard-rate function with cosines expansion, $\mathrm{AIC}=794.38, \mathrm{DP}=83.5 \%, \mathrm{CV}=14.7 \%, n=293$ bird observations) and 4.51 birds ha ${ }^{-1}$ in abandoned pastures (Hazard-rate function with cosines expansion, AIC $=1,174.07$, $\mathrm{DP}=91.0, \mathrm{CV}=12.6 \%, n=428$ bird observations).

In respect to pasture position, there were no statistically significant differences in species richness and total bird abundance between studied habitat categories (Tukey HSD: for all comparisons $P>0.07)$, except for species diversity which was found to be higher in valleys than on hill crests (Tukey HSD: $M S_{137}=0.05, P=0.035$ ).

Table 2. Comparison of environmental variables between grazed and abandoned upland pastures in IBA Ponor ( $t$-test for independent samples, StatSoft 2004).

\begin{tabular}{|c|c|c|c|c|}
\hline \multirow[t]{2}{*}{ Environmental variables } & \multicolumn{2}{|l|}{ Means ( \pm SE) } & \multirow[t]{2}{*}{$t(\mathrm{df}=14 \mathrm{I})$} & \multirow[t]{2}{*}{$P^{*}$} \\
\hline & $\begin{array}{l}\text { Abandoned pastures } \\
(n=89)\end{array}$ & $\begin{array}{l}\text { Grazed pastures } \\
(n=54)\end{array}$ & & \\
\hline Elevation (m) & $1,351.44 \pm 6.11$ & $1255.59 \pm 8.21$ & 9.47 & $<0.001$ \\
\hline Cover of short sward (\%) & $87.22 \pm 1.12$ & $77 \cdot 76 \pm 2.46$ & 3.46 & $<0.001$ \\
\hline Cover of tall sward (\%) & $2.78 \pm 0.69$ & $4.28 \pm 1.67$ & 0.44 & 0.660 \\
\hline Cover of short shrubs (\%) & $4.69 \pm 0.68$ & $5.26 \pm 0.72$ & -1.56 & 0.121 \\
\hline Cover of tall shrubs (\%) & $1.28 \pm 0.25$ & $4.48 \pm 0.72$ & -4.80 & $<0.001$ \\
\hline Cover of trees $(\%)$ & $1.54 \pm 0.43$ & $0.82 \pm 0.27$ & -1.95 & 0.054 \\
\hline Cover of rocks and stones (\%) & $2.98 \pm 0.51$ & $4.87 \pm 0.9$ & -2.51 & 0.013 \\
\hline Habitat heterogeneity & $0.41 \pm 0.03$ & $0.62 \pm 0.05$ & -4.16 & $<0.001$ \\
\hline Richness of habitat structures & $3.40 \pm 0.10$ & $3.87 \pm 0.16$ & -2.41 & 0.017 \\
\hline
\end{tabular}

${ }^{*}$ Significant $P$-values of the $t$-test are in bold. 
Table 3. The effects of upland pasture use, position and their interaction on the avian community parameters in IBA Ponor (GLM, StatSoft 2004).

\begin{tabular}{lllllll}
\hline $\begin{array}{l}\text { Bird community } \\
\text { parameter }\end{array}$ & $R^{2}$ & Effect & $F$ & df & $P^{*}$ & Interpretation \\
\hline Species richness & \multirow{2}{*}{0.50} & Pasture use & 6.92 & 3,126 & $\mathbf{0 . 0 0 9}$ & grazed $>$ abandoned \\
& & Pasture position & 3.40 & 2,137 & $\mathbf{0 . 0 3 6}$ & valley $>$ slope $>$ crest \\
& & Interaction & $<0.01$ & 2,137 & 0.991 & \\
Species diversity & \multirow{2}{*}{0.47} & Pasture use & 7.16 & 1,137 & $\mathbf{0 . 0 0 8}$ & grazed $>$ abandoned \\
& & Pasture position & 4.37 & 2,137 & $\mathbf{0 . 0 1 4}$ & valley $>$ crest \\
& & Interaction & 0.09 & 2,137 & 0.911 & \\
Total abundance & \multirow{2}{*}{0.35} & Pasture use & 2.03 & 1,137 & 0.15 & \\
& & Pasture position & 1.93 & 2,137 & 0.15 & \\
& & Interaction & 0.07 & 2,137 & 0.927 & \\
\hline
\end{tabular}

* Significant $P$-values are in bold.

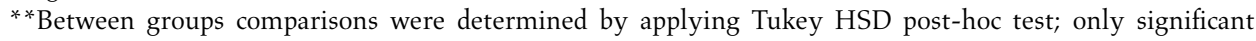
differences $(P<0.05)$ are shown.

Analyzed separately, grassland specialists did not show differences in species richness and abundance between grazed and abandoned pastures (Mann Whitney $U$ test: $U=2,383.5, P=0.995$ and $U=2,181.5, P=0.395$ for species richness and abundance respectively). The group of scrubland/woodland species had higher species richness and abundance in grazed than in abandoned pastures (Mann Whitney $U$ test: $U=1,718.0, P=0.005$ and $U=1,695, P=0.004$ for species richness and abundance respectively). The mean species richness of scrub/woodland species was $1.23 \pm 0.20$ species per point count station in grazed pastures $(n=54)$ and $0.58 \pm 0.09$ species per point count station in abandoned pastures $(n=89)$, and the mean abundance was $1.57 \pm 0.25$ birds per point count station in grazed pastures $(n=54)$ and $0.71 \pm 0.12$ birds per point count station in abandoned pastures $(n=89)$.

From all recorded species, 21 were observed more frequently in extensively used pastures and Io species were more frequent in abandoned pastures (Appendix 1 ). Among them, 12 species were found exclusively in grazed pastures, while three species were recorded only in abandoned pastures. Most of these species had too small sample sizes (with less than five records) to make reliable inferences about their habitat preferences, but Wood Lark $(n=5)$ can be considered to prefer grazed pastures. From the 11 species analysed for their habitat preferences, statistically significant results were obtained for seven species (Table 4). Five of them showed preference for grazed pastures (Northern Wheatear, Barred Warbler, Red-backed Shrike, Yellowhammer and Corn Bunting) and two species showed preference for abandoned pastures (Eurasian Skylark and Tree Pipit).

\section{Discussion}

\section{Structural complexity and features within pastures}

The results from the present study support the thesis that habitat structural complexity is very important in influencing bird usage of grasslands (Atkinson et al. 2004, Benton et al. 2003). The positive relationship found between bird species richness and diversity on the one hand, and habitat heterogeneity and structural richness on the other, could be explained by the increase in ecological niches for birds (McCracken and Tallowin 2004). The positive effect of farmland habitat complexity on bird diversity was also shown for other regions in south-eastern (Kati and Sekercioglu 2006) and Central Europe (Verhulst et al. 2004). In the studied area, scrubland cover was found to increase bird diversity within pastures and a similar effect was observed by Vallecilo et al. (2008) for Europe and by Tubelis and Cavalcanti (2000) for South America where scrubby pastures held more species than cleared ones.

Habitat use by birds breeding in pastures is known to be affected mainly by suitable nest and foraging site availability (Söderström and Part 2000). In the present study, there were two main 
Table 4. Selection indices of eleven breeding bird species in grazed and abandoned upland pastures in IBA Ponor (G-test was applied to determine if birds select habitats at random).

\begin{tabular}{|c|c|c|c|c|c|}
\hline \multirow[t]{2}{*}{ Species* } & \multirow{2}{*}{$\begin{array}{l}\text { Number of } \\
\text { birds recorded }\end{array}$} & \multicolumn{2}{|c|}{ Selection index $( \pm \mathrm{SE})$} & \multirow{2}{*}{$\begin{array}{l}G \\
(\mathrm{df}=1)\end{array}$} & \multirow[t]{2}{*}{$P^{* * *}$} \\
\hline & & Grazed pastures & Abandoned pastures & & \\
\hline Crex crex & 12 & $0.88 \pm 0.36$ & $1.07 \pm 0.22$ & 0.10 & 0.752 \\
\hline Alauda arvensis & 294 & $0.83 \pm 0.07$ & $1.10 \pm 0.04$ & $5 \cdot 37$ & 0.021 \\
\hline Anthus trivialis & 52 & $0.46 \pm 0.14$ & $1.33 \pm 0.08$ & 10.40 & 0.001 \\
\hline Oenanthe oenanthe & 41 & $1.81 \pm 0.19$ & $0.51 \pm 0.12$ & 15.64 & $<0.001$ \\
\hline Saxicola rubetra & 129 & $0.92 \pm 0.11$ & $1.05 \pm 0.07$ & 0.46 & 0.498 \\
\hline Sylvia nisoria & 8 & $1.99 \pm 0.41$ & $0.40 \pm 0.25$ & 4.59 & 0.032 \\
\hline Lanius collurio & 84 & $1.32 \pm 0.14$ & $0.80 \pm 0.09$ & 5.19 & 0.023 \\
\hline Carduelis cannabina & 31 & $1.11 \pm 0.24$ & $0.93 \pm 0.14$ & 0.23 & 0.632 \\
\hline C. chloris & 7 & $0.38 \pm 0.35$ & $1.38 \pm 0.21$ & 1.90 & 0.168 \\
\hline Emberiza citrinella & 15 & $1.77 \pm 0.32$ & $0.54 \pm 0.20$ & 5.12 & 0.024 \\
\hline Miliaria calandra & 10 & $2.38 \pm 0.25$ & $0.16 \pm 0.15$ & 11.98 & $<0.001$ \\
\hline
\end{tabular}

*Only abundant species (observations $>5$ ) are shown.

${ }^{*}$ For each species, maximum number of individuals recorded on each point count station from both visits was considered.

***Significant $P$-values of the $G$-test are in bold.

environmental gradients determining bird species occurrences (vegetation height and habitat moisture) and the main habitat features for birds within the upland pastures of western Bulgaria were the scrubland cover, elevation, short sward cover and cover of stony ground. The positive association of Eurasian Skylark with elevation supports the statement that the upland seminatural grasslands are of significant importance for the species (Chamberlain and Gregory 1999, Browne et al. 2000). The strong effect of sward height on bird species habitat use is also well known (McCracken and Tallowin 2004) and according to Atkinson et al. (2004) birds that feed on soil invertebrates prefer shorter swards with larger amounts of bare earth. In the present study, such species were the Northern Wheatear (as was also found in Western Europe by Fuller and Gough 1999) and Eurasian Linnet. Although some discrepancies exist (in respect to Corn Bunting that were found to avoid hedges in the study by Mason and Macdonald 2000), the results from the present study confirm the positive relationship between many farmland birds and scrub: i.e. for Wood Lark (Sitters et al. 1996, Kati and Sekercioglu 2006), Barred Warbler and Red-backed Shrike (Iankov 2007), European Greenfinch (Fuller et al. 2001), Yellowhammer and Corn Bunting (Kati and Sekercioglu 2006). The importance of this structural feature was determined not only because it increases avian diversity, but because it supports several species with high conservation status or declining populations in Bulgaria: Wood Lark, Barred Warbler, Red-backed Shrike and Corn Bunting, the first three being on Annex I of the EU Birds Directive, and the latter two with negative national populations trends (Spasov 2008).

\section{Land abandonment}

Contrary to the expectations that abandoned pastures should have more complex habitat structure due to vegetation succession (Preiss et al. 1997, Verhulst et al. 2004), the results from this study showed that extensively grazed animals can maintain a high structural complexity of habitat. However, this phenomenon should not be attributed as much to the effect of grazing intensity, as to the landscape context because of the small number of sheep and extensive use of pastures. A possible explanation is that pasture abandonment primarily affects the least productive and low quality lands (Sirami et al. 2008). In IBA Ponor, these were pastures at higher elevation and on crests (in abandoned pastures, 39\% of the study plots were located on crests versus $30 \%$ in valleys) where the shallower soil, stronger winds and drier microclimate can impede development of scrub and woody vegetation. In contrast, grazed pastures were 
located at lower elevation and in valleys (in grazed pastures, $45 \%$ of the study plots were located in valleys versus $14 \%$ on crests) where land was more productive, benefiting development of more heterogeneous vegetation cover. Active pastures are generally associated with less scrubland than abandoned ones and the presence of shrubs and trees within grazed pastures in Ponor could be due to the low number of grazing animals (McCracken and Tallowin 2004) but it is also possible that sheep help dispersal of shrub seeds (Manzano et al. 2005). Although there was a difference in altitude and landscape position between the studied habitat types, this bias should not be strong; the difference in mean elevation between grazed and abandoned pastures was only about $100 \mathrm{~m}$ and the interaction between pasture use and position was not statistically significant. Moreover, this study investigates a real situation in semi-natural grasslands resulting from the local landscape and socio-economic conditions, and similar effects should be expected from other upland or foothills areas in Bulgaria.

The present study contradicts the findings that abandoned pastures support higher avian diversity and richness than extensively used pastures (Verhulst et al. 2004) and that scrubland and woodland species benefit from pasture abandonment (Preiss et al. 1997, MacDonald et al. 2000, Suárez-Seoane et al. 2002, Verhulst et al. 2004, Vallecillo et al. 2008). The results are not consistent across these studies, probably because in Ponor the habitat complexity was higher in grazed pastures, while in the others it was higher in abandoned pastures. Other factors, such as the historical and landscape context, could also be considered to influence the results of the present study: in the distant past the studied grasslands were covered by forests, and at present, the studied upland pastures were located within scrubland and woodland matrix that implies higher occurrence of scrubland/woodland species (Söderström and Part 200o). The finding that higher structural complexity of grazed pastures determined more diverse and species-rich bird communities than abandoned pastures supports the idea that land abandonment negatively affects farmland birds (Ahnström et al. 2008, Sirami et al. 2008).

In the present study, overall bird abundance was similar between grazed and abandoned pastures but at the species level, clear differences were found. Many authors relate rates of bird occurrences in grasslands with the presence of grazing animals (e.g. Tucker 1992, Buckingham et al. 2004) but results are not consistent over the studies. Eurasian Skylark is known to benefit from abandoned pastures in Britain (Fuller et al. 2004), but it was found to prefer extensively used pastures in Central Europe (Verhulst et al. 2004). Wood Lark, Red-backed Shrike and Corn Bunting are known to increase over time with land abandonment in south-western and Central Europe (Verhulst et al. 2004, Sirami et al. 2008), while in the present study these species preferred grazed pastures. The lack of evidence that corvids and other passerines (Eurasian Blackbird Turdus merula, Hedge Accentor Prunella modularis, European Goldfinch Carduelis carduelis and Ortolan Bunting Emberiza hortulana) are sensitive to land abandonment (Preiss et al. 1997, Atkinson et al. 2004, Buckingham et al. 2004, Fuller et al. 2004, Berg 2008) is probably due to the small sample sizes of these birds in the present study.

When comparing different habitat types, it is not enough only to show that there are more species in one of the studied habitats, but it is also important to evaluate their conservation status (Batáry et al. 2007b). In the present study, species recorded in grazed pastures had higher conservation status than those in abandoned pastures. Three species associated with grazed pastures are included in Annex 1 of the Birds Directive and three are listed in SPEC 2 and 3, while none of the species benefiting from abandoned pastures was included in these categories. From the species preferring abandoned pastures, only one (Eurasian Skylark) had a decreasing population, while two of the species associated with grazed pastures (Red-backed Shrike and Corn Bunting) had negative population trends (Spasov 2008).

\section{Management implications}

So far, several studies have shown that extensive farming benefits wildlife conservation in Europe (e.g. Benton et al. 2002, Stoate et al. 2003, Verhulst et al. 2004, Vickery et al. 2004). The present 
study supports this thesis and demonstrated that extensive grazing is an optimal conservation strategy for sustainable wildlife management within agricultural lands. Apart from the higher complexity of structures they provide for breeding, the grasslands under moderately intensive management are more likely to provide optimum foraging opportunities for birds (McCracken and Tallowin 2004). In respect to the National Policy (NP) related to the Agro-environmental Programme, the results of the present study confirm the need to promote extensive grazing (National standard 4.I for maintaining the land in good agricultural and ecological condition). However, sheep density was found to be low in the studied area (about 0.2 sheep ha ${ }^{-1}$ ) and the NP should stimulate the increase of sheep numbers within such less favoured areas. On the other hand, the obtained results contradict the need for scrub removal from pastures promoted by the NP. According to National standard 4.2 for maintaining the land in good agricultural and ecological condition, stakeholders are obligated to remove shrub vegetation from constantly used pastures with the aim of maintaining natural habitat in 'good' condition. This study clearly showed that availability of shrubs is important to many bird species (including several with high conservational value or decreasing populations in Bulgaria), and the removal of this habitat feature may seriously damage the structure of grassland bird assemblages. Moreover, part of the scrubland vegetation within the studied grasslands is protected by Habitats Directive (92/43/EEC): Juniperus communis formations on heaths or calcareous grasslands (code 5130) and arborescent matorral with Juniperus spp. (code 5210). In conclusion, for the sustainable management of upland pastures of western Bulgaria with respect to their avian diversity conservation, maintenance of habitat complexity within pastures through extensive grazing should be promoted, ensuring availability of scrubland and woodland vegetation (about 15\%) wherever possible.

\section{Acknowledgements}

This study was initiated by the project "Conservation of globally important biodiversity in high nature value semi-natural grasslands through support for the traditional local economy" of the Bulgarian Society for the Protection of Birds / BirdLife Bulgaria, funded by the UNDP (Project No. 43595) and GEF (Project ID 2730). Georgi Popgeogiev provided the GIS data, and Kiril Vassilev and Hristo Pedashenko provided the floristic data. The manuscript was proof-read by Ian Fisher, and enhanced by constructive comments from two anonymous referees.

\section{References}

Ahnström, J., Berg, $\AA$. and Söderlund, H. (2008) Birds on farmsteads - effects of landscape and farming characterisitcs. Ornis Fennica 85: 98-108.

Atkinson, P. W., Buckingham, D. and Morris, A. J. (2004) What factors determine where invertebrate-feeding birds forage in dry agricultural grasslands? Ibis 146 (Suppl. 2): 99-107.

Báldi, A., Batáry, P. and Erdös, S. (2005) Effects of grazing intensity on bird assemblages and populations of Hungarian grasslands. Agr. Ecosyst. Environ. 108: 251-263.

Batáry, P., Báldi, A. and Erdös, S. (2007a) Grassland versus non-grassland bird abundance and diversity in managed grasslands: local, landscape and regional scale effects. Biodivers. Conserv. 16: 871-881.

Batáry, P., Báldi, A. and Erdös, S. (2007b) The effects of using different species conservation priority lists on the evaluation of habitat importance within Hungarian grasslands. Bird Conserv. Int. 17: 35-43.

Benton, T. G., Bryant, D. M., Cole, L. and Crick, H. Q. P. (2002) Linking agricultural practice to insect and bird populations: a historical study over three decades. J. Appl. Ecol. 39: 673-687.

Benton, T. G., Vickery, J. A. and Wilson, J. D. (2003) Farmland biodiversity: is habitat heterogeneity the key? Trends Ecol. Evol. 18: 182-188. 
Berg, A. (2008) Habitat selection and reproductive success of Ortolan Buntings Emberiza hortulana on farmland in central Sweden - the importance of habitat heterogeneity. Ibis 150: 565-573.

Browne, S., Vickery, J. and Chamberlain, D. (2000) Densities and population estimates of breeding Skylarks Alauda arvensis in Britain in 1997. Bird Study 47: 52-65.

Buckingham, D. L., Peach, W. J. and Fox, D. S. (2004) Effects of agricultural management on the use of lowland grassland in the UK by foraging birds. Sandy, UK: RSPB.

Buckland, S., Anderson, D., Burnham, K., Laake, J., Borchers, D. and Thomas, L. (2001) Introduction to distance sampling. London, UK: Oxford University Press.

Chamberlain, D. E. and Gregory, R. D. (1999) Coarse and fine scale habitat associations of breeding Skylarks Alauda arvensis in the UK. Bird Study 46: 34-47.

Donald, P. F., Green, R. E. and Heath, M. F. (2001) Agricultural intensification and the collapse of Europe's farmland bird populations. Proc. R. Soc. B 268: 25-29.

Donald, P. F., Sanderson, F. J., Burfield, I. J. and van Bommel, F. P. J. (2006) Further evidence of continent-wide impacts of agricultural intensification of European farmland birds, 1990-2000. Agr. Ecosyst. Environ. 116: 189-196.

Fuller, R. J. and Gough, S. J. (1999) Changes in sheep numbers in Britain: implications for bird populations. Biol. Conserv. 91: 7389.

Fuller, R. J., Chamberlain, D. E., Burton, N. H. K. and Gough, S. J. (2001) Distributions of birds in lowland agricultural landscapes of England and Wales: how distinctive are bird communities of hedgerows and woodland? Agr. Ecosyst. Environ. 84: 79-92.

Fuller, R. J., Hinsley, S. A. and Swernam, R. D. (2004) The relevance of non-farmland habitats, uncropped areas and habitat diversity to the conservation of farmland birds. Ibis 146 (Suppl. 2): 22-31.

Gibbons, D. W. and Gregory, R. D. (2006) Birds. Pp. 308-350 in W. J. Sutherland, ed. Ecological census techniques - a handbook. $2^{\text {nd }}$ edn. Cambridge, UK: Cambridge University Press.
Graham, M. (2003) Confronting multicollinearity in ecological multiple regression. Ecology 84: 2804-2815.

Hannah, L., Carr, L. J. and Lankerani, A. (1995) Human disturbance and natural habitat: a biome level analysis of a global data set. Biodivers. Conserv. 4: 128-155.

Iankov, P. (2007) Atlas of breeding birds in Bulgaria. Sofia, Bulgaria: Bulgarian Society for the Protection of Birds.

Kati, V. I. and Sekercioglu, C. H. (2006) Diversity, ecological structure, and conservation of the landbird community of Dadia reserve, Greece. Divers. Distrib. 12: 620629.

Klimešová, J., Latzel, V., de Bello, F. and van Groenendael, J. M. (2008) Plant functional traits in studies of vegetation changes in response to grazing and mowing: towards a use of more specific traits. Preslia 80: 245-253.

Krebs, C. (1999) Ecological methodology. $2^{\text {nd }}$ edn. Menlo Park, California: Benjamin / Cummings.

MacDonald, D., Crabtree, J. R., Weisinger, G., Dax, Y., Stamou, N., Fleury, P., Guttierez Lazpita, J. and Gibbons, A. (2000) Agricultural abandonment in mountain areas of Europe: environmental consequences and policy response. J. Environ. Manage. 59: 47-69.

Manly, B., McDonald, L. and Thomas, D. (1993) Resource selection by animals: statistical design and analysis for field studies. London, UK: Chapman \& Hall.

Manzano, P., Malo, J. E. and Peco, B. (2005) Sheep gut passage and survival of Mediterranean shrub seeds. Seed Sci. Res. 15: 2128.

Mason, C. F. and Macdonald, S. M. (2000) Corn Bunting Miliaria calandra populations, landscape and land-use in an arable district of eastern England. Bird Conserv. Int. 10: 169-186.

McCracken, D. I. and Tallowin, J. R. (2004) Swards and structure: the interactions between farming practices and bird food resources in lowland grasslands. Ibis 146 (Suppl. 2): 108-114.

Nikolov, S. C. and Vassilev, V. (2004) Breeding bird atlas of the Ponor Mountains, western Bulgaria. Sandgrouse 26: 7-22. 
Nikolov, S. C., Tonchev, B., Barov, B. and Stoyanov, G. (2007) Ponor. Pp: 136-137 in I. Kostadinova and M. Gramatikov, eds. Important Bird Areas in Bulgaria and NATURA 200o. Sofia, Bulgaria: Bulgarian Society for the Protection of Birds.

Ostermann, O. P. (1998) The need for management of nature conservation sites designated under Natura 2000. J. Appl. Ecol. 35: 968-973.

Pavel, V. (2004) The impact of grazing animals on nesting success of grassland passerines in farmland and natural habitats: a field experiment. Folia Zool. 53: 171-178.

Perlut, N. G., Strong, A. M., Donovan, T. M. and Buckley, N. J. (2008) Regional population viability of grassland songbirds: Effects of agricultural management. Biol. Conserv. 141: 3139-3151.

Preiss, E., Martin, J.-L. and Debussche, M. (1997) Rural depopulation and recent landscape changes in a Mediterranean region: Consequences to the breeding avifauna. Landsc. Ecol. 12: 51-61.

Rook, A. J. and Tallowin, J. R. B. (2003) Grazing and pasture management for biodiversity benefit. Anim. Res. 52: 181-189.

Sirami, C., Brotons, L., Burfield, I., Fonerflick, J. and Martin, J.-L. (2008) Is land abandonment having impact on biodiversity? A meta-analytical approach to bird distribution changes in the north-western Mediterranean. Biol. Conserv. 141: 450-459.

Sitters, H. P., Fuller, R. J., Hoblyn, R. A., Wright, M. T., Cowie, N. and Bowden, C. G. R. (1996) The Woodlark Lullula arborea in Britain: population trends, distribution and habitat occupancy. Bird Study 43: $172-187$.

Söderström, B. and Part, T. (200o) Influence of landscape scale on farmland birds breeding in semi-natural pastures. Conserv. Biol. 14: 522-533.

Spasov, S. (2008) The state of Bulgaria's common birds. Sofia, Bulgaria: Bulgarian Society for the Protection of Birds.

StatSoft (2004) STATISTICA 7.o. Data analysis software. Tulsa, USA: StatSoft Inc. http://www.statsoft.com/

Stoate, C., Araújo, M. and Borralho, R. (2003) Conservation of European farmland birds: abundance and species diversity. Ornis Hungarica 12-13: 33-40.

Suárez-Seoane, S., Osborne, P. E. and Baudry, J. (2002) Responses of birds of different biogeographic origins and habitat requirements to agricultural land abandonment in northern Spain. Biol. Conserv. 105: 333344 .

ter Braak, C. J. F. and Smilauer, P. (2002) Canoco for Windows. Version 4.5. Wageningen, The Netherlands: Biometris - Plant Research International.

Tews, J., Brose, U., Grimm, V., Tielbörger, K., Wichmann, M. C., Schwager, M. and Jeltsch, F. (2004) Animal species diversity driven by habitat heterogeneity/diversity: the importance of keystone structures. J. Biogeogr. 31: 79-92.

Thomas, L., Laake, J., Strindberg, S., Marques, F., Buckland, S., Borchers, D., Anderson, D., Burnham, K., Hedley, S., Pollard, J., Bishop, J. and Marques, T. (2006) Distance 5.0. Release 2. St Andrews, UK: University of St. Andrews, Research Unit for Wildlife Population Assessment. http://www.ruwpa. st-and.ac.uk/distance/

Tubelis, D. P. and Cavalcanti, R. B. (2000) A comparison of bird communities in natural and disturbed non-wetland open habitats in the Cerrado's central region, Brazil. Bird Conserv. Int. 10: 331-350.

Tucker, G. M. (1992) Effects of agricultural practices on field use by invertebratefeeding birds in winter. J. Appl. Ecol. 29: 779-790.

Vallecillo, S., Brotons, L. and Herrando, S. (2008) Assessing the response of openhabitat bird species to landscape changes in Mediterranean mosaics. Biodiv. Conserv. 17: 103-119.

Verhulst, J., Báldi, A. and Kleijn, D. (2004) The relation between land-use intensity and species-richness and abundance of birds in Hungary. Agr. Ecosyst. Environ. 104: 465-473.

Vickery, J. A., Bradbury, R. B., Henderson, I. G., Eaton, M. A. and Grice, P. V. (2004) The role of agri-environment schemes and farm management practices in reversing the decline of farmland birds in England. Biol. Conserv. 119: 19-39. 
STOYAN C. NIKOLOV

Central Laboratory of General Ecology - BAS, 2 Yurii Gagarin Str., 1113 Sofia, Bulgaria. Email: nikoloviooyan@abv.bg

Received 25 February 2009; revision accepted 6 July 2009;

Published online 30 November 2009

\section{Appendix 1}

Breeding birds recorded in the upland pastures of IBA Ponor, western Bulgaria in 2008. Description of main habitats, conservation status and population trends follow Iankov (2007) and Spasov (2008).

\begin{tabular}{|c|c|c|c|c|c|}
\hline Species & $\begin{array}{l}\text { Main } \\
\text { habitat }\end{array}$ & $\begin{array}{l}\text { Conservation } \\
\text { status }\end{array}$ & $\begin{array}{l}\text { Trend in } \\
\text { Bulgaria }\end{array}$ & $\begin{array}{l}F_{G P}(\%) \\
(n=54)\end{array}$ & $\begin{array}{l}F_{A P}(\%) \\
(n=89)\end{array}$ \\
\hline $\begin{array}{l}\text { Common Quail Coturnix } \\
\text { coturnix }\end{array}$ & G & $\mathrm{SPEC}_{3}$ & $\downarrow \downarrow$ & 0.6 & 5.6 \\
\hline Corncrake Crex crex & G & $\operatorname{SPEC}_{1}$ & - & 5.6 & 7.9 \\
\hline $\begin{array}{l}\text { Eurasian Skylark Alauda } \\
\text { arvensis }\end{array}$ & G & & $\downarrow$ & 79.6 & 94.9 \\
\hline $\begin{array}{l}\text { Wood Lark Lullula } \\
\text { arborea }\end{array}$ & G & SPEC 2 & - & 10.2 & 0.0 \\
\hline $\begin{array}{l}\text { Tawny Pipit Anthus } \\
\text { campestris }\end{array}$ & G & $\operatorname{SPEC}_{3}$ & - & 1.9 & 1.1 \\
\hline Tree Pipit A. trivialis & G & & - & 14.8 & 40.4 \\
\hline $\begin{array}{l}\text { Grey Wagtail Motacilla } \\
\text { cinerea }\end{array}$ & $\mathrm{O}$ & & - & 1.9 & 3.4 \\
\hline $\begin{array}{l}\text { Hedge Accentor Prunella } \\
\text { modularis }\end{array}$ & SW & & - & 1.9 & 0.0 \\
\hline $\begin{array}{l}\text { Northern Wheatear } \\
\text { Oenanthe oenanthe }\end{array}$ & G & $\operatorname{SPEC}_{3}$ & - & 38.0 & 12.4 \\
\hline $\begin{array}{l}\text { Isabelline Wheatear } \\
\text { O. isabellina }\end{array}$ & G & & - & 3.7 & 0.0 \\
\hline $\begin{array}{l}\text { Whinchat Saxicola } \\
\text { rubetra }\end{array}$ & G & & - & $44 \cdot 4$ & 61.2 \\
\hline $\begin{array}{l}\text { Rufous-tailed Rock- } \\
\text { thrush Monticola } \\
\text { saxatilis }\end{array}$ & $\mathrm{O}$ & $\mathrm{SPEC}_{3}$ & - & 0.0 & 1.1 \\
\hline $\begin{array}{l}\text { Mistle Thrush Turdus } \\
\text { viscivorus }\end{array}$ & SW & & - & 0.9 & 0.6 \\
\hline $\begin{array}{l}\text { Eurasian Blackbird } \\
\text { T. merula }\end{array}$ & SW & & $*$ & 3.7 & 1.7 \\
\hline Ring Ouzel T. torquatus & SW & & - & 0.0 & $3 \cdot 4$ \\
\hline $\begin{array}{l}\text { Barred Warbler Sylvia } \\
\text { nisoria }\end{array}$ & SW & & - & $9 \cdot 3$ & 2.2 \\
\hline $\begin{array}{l}\text { Common Whitethroat } \\
\text { S. communis }\end{array}$ & SW & & $\uparrow \uparrow$ & 2.8 & 0.0 \\
\hline Great Tit Parus major & SW & & * & 0.9 & 0.0 \\
\hline $\begin{array}{l}\text { Red-backed Shrike } \\
\text { Lanius collurio }\end{array}$ & SW & $\operatorname{SPEC}_{3}$ & $\downarrow$ & 43.5 & 37.1 \\
\hline $\begin{array}{l}\text { Black-billed Magpie Pica } \\
\text { pica }\end{array}$ & SW & & $*$ & 0.9 & 0.0 \\
\hline
\end{tabular}


Appendix I. C.c ntinued.

\begin{tabular}{|c|c|c|c|c|c|}
\hline Species & $\begin{array}{l}\text { Main } \\
\text { habitat }\end{array}$ & $\begin{array}{l}\text { Conservation } \\
\text { status }\end{array}$ & $\begin{array}{l}\text { Trend in } \\
\text { Bulgaria }\end{array}$ & $\begin{array}{l}F_{G P}(\%) \\
(n=54)\end{array}$ & $\begin{array}{l}F_{A P}(\%) \\
(n=89)\end{array}$ \\
\hline $\begin{array}{l}\text { Carrion Crow Corvus } \\
\text { corone }\end{array}$ & SW & & * & 1.9 & 0.0 \\
\hline $\begin{array}{l}\text { Common Starling } \\
\text { Sturnus vulgaris }\end{array}$ & SW & & $\downarrow$ & 1.9 & 0.0 \\
\hline $\begin{array}{l}\text { Eurasian Tree Sparrow } \\
\text { Passer montanus }\end{array}$ & SW & & $*$ & 1.9 & 0.0 \\
\hline $\begin{array}{l}\text { Eurasian Chaffinch } \\
\text { Fringilla coelebs }\end{array}$ & SW & & $*$ & 0.0 & 2.2 \\
\hline $\begin{array}{l}\text { Eurasian Linnet } \\
\quad \text { Carduelis cannabina }\end{array}$ & G & & - & 22.2 & 13.5 \\
\hline $\begin{array}{l}\text { European Goldfinch } \\
\text { C. carduelis }\end{array}$ & SW & & * & 1.9 & 0.0 \\
\hline $\begin{array}{l}\text { European Greenfinch } \\
\text { C. chloris }\end{array}$ & SW & & $*$ & 1.9 & $3 \cdot 4$ \\
\hline $\begin{array}{l}\text { Hawfinch } \\
\text { Coccothraustes } \\
\text { coccothraustes }\end{array}$ & SW & & - & 0.9 & 0.0 \\
\hline $\begin{array}{l}\text { Ortolan Bunting } \\
\text { Emberiza hortulana }\end{array}$ & SW & SPEC 2 & * & 3.7 & 0.0 \\
\hline $\begin{array}{l}\text { Yellowhammer } \\
\text { E. citrinella }\end{array}$ & SW & & - & 18.5 & 5.6 \\
\hline $\begin{array}{l}\text { Corn Bunting Miliaria } \\
\text { calandra }\end{array}$ & SW & & $\downarrow \downarrow$ & 15.7 & 0.6 \\
\hline
\end{tabular}

Main habitats: grassland (G), scrubland/woodland (SW), and other (O); Population trend: steep decline $(\downarrow \downarrow)$, moderate decline $(\downarrow)$, stable $(-)$, strong increase $(\uparrow \uparrow)$, uncertain $\left({ }^{*}\right) ; F_{G P}$ and $F_{A P}$ indicate bird frequency in grazed and abandoned pastures, respectively. 